\title{
Feeding of the bivalve Theora Iubrica on benthic microalgae: isotopic evidence
}

\author{
H. Yokoyama*, Y. Ishihi \\ National Research Institute of Aquaculture, Fisheries Research Agency, Nansei, Mie 516-0193, Japan
}

\begin{abstract}
A stable isotope study was conducted to identify the sources of nutrition for the semelid bivalve Theora lubrica living in estuarine subtidal sediments. Along an estuarine gradient in Gokasho Bay, central Japan, $\delta^{13} \mathrm{C}$ and $\delta^{15} \mathrm{~N}$ were determined both in tissues of T. lubrica and its potential food sources, i.e. particulate organic matter (POM) from riverine and marine sites, sedimentary organic matter (SOM) and microalgae on an intertidal mudflat. Differences existed among $\delta^{13} \mathrm{C}$ and $\delta^{15} \mathrm{~N}$ in riverine POM (yearly mean value: $-26.5 \%$ and $0.5 \%$, respectively), marine POM $(-20.4 \%$, $6.3 \%$ ) and benthic microalgae $(-14.7 \%, 4.9 \%)$. SOM exhibited a gradual isotopic enrichment both in ${ }^{13} \mathrm{C}$ and ${ }^{15} \mathrm{~N}$ from the estuarine station adjacent to the mudflats to the more seaward stations, indicating a progressive mixing of terrestrial and marine sources. However, the isotopic composition of $T$. lubrica did not follow this trend: as the sampling station was shifted seaward, $\delta^{15} \mathrm{~N}$ increased from 7.5 to $9.4 \%$, whereas $\delta^{13} \mathrm{C}$ decreased from -16.0 to $-17.8 \%$. These values cannot be due to the utilization of terrestrial organic matter carried by the river inflow. The observed spatial variation in the $\delta^{13} \mathrm{C}$ values suggest that $T$. lubrica has 2 dominant food sources, i.e. benthic microalgae (mainly diatoms) and marine POM (mainly coastal phytoplankton), and that in subtidal areas near the mudflats benthic microalgae were an important dietary component.
\end{abstract}

KEY WORDS: Stable isotope - Benthic microalgae . Macrobenthos · Estuary $\cdot$ Theora lubrica

Resale or republication not permitted without written consent of the publisher

Estuaries are among the most productive ecosystems in the world, and are characterized by inputs of terrestrial and marine organic matter in addition to autochthonous production by macroalgae, microalgae and seagrasses. Recent research has focused on the fate and pathways of this organic matter in the estuarine ecosystem. Stable carbon isotope ratios have been extensively used to evaluate the mixing processes between terrestrial and marine organic matter in estuaries (e.g. Peters et al. 1978, Fontugne \& Jouanneau
1987), and to elucidate the sources of nutrition for consumers inhabiting such areas (reviewed by Fry \& Sherr 1984) based on the small isotope fractionation between different trophic levels (DeNiro \& Epstein 1978). In addition, stable nitrogen ratios also can be used to deduce the mixing ratio of terrestrial and marine sources in cases of a clear difference of values between these 2 sources (reviewed by Owens 1987), and can be used to estimate the dietary proportion of different food sources by examining the spatial variation of values within a single species (e.g. France 1994). Thus, the coupling of $\delta^{13} \mathrm{C}$ and $\delta^{15} \mathrm{~N}$ values may provide more precise information.

The semelid bivalve Theora lubrica Gould lives in estuarine soft bottom habitats in Japan, and especially occurs as a dominant species in eutrophic shallow lagoons and bays (Horikoshi 1990, Kikuchi 1991). This species was originally distributed in East Asia, but in recent years, its distributional area has expanded to Australia (Poore \& Rainer 1979) and New Zealand (Hayward et al. 1997), probably due to artificial introductions through the release of ballast water from ships. T. lubrica in Japan is characterized by a small adult size (up to $15 \mathrm{~mm}$ in shell length), short life span (several months), and rapid growth and maturation (age of 1 to $3 \mathrm{mo}$ at first reproduction) (Kikuchi \& Tanaka 1976, Imabayashi \& Tsukuda 1984). Populations of this species often diminish due to hypoxic waters; thereafter, reconstruction of a population is quickly attained by settlement of planktonic larvae after the recovery of the dissolved oxygen due to its ability to reproduce throughout the year (Kikuchi \& Tanaka 1976, Imabayashi \& Tsukuda 1984, Imabayashi 1986). T. lubrica lies buried in the sediment and feeds on particles on the sediment surface by extending the inhalant siphon (Kikuchi 1981). Despite extensive information on the ecology of this species, however, its 
food sources have not yet been identified. The present study focused on the spatial variation of the isotopic composition of T. lubrica sampled along a transect of an estuarine soft bottom area in Gokasho Bay to identify its nutrition by comparing its $\delta^{13} \mathrm{C}$ and $\delta^{15} \mathrm{~N}$ with that of the potential food sources.

Materials and methods. Study area: Gokasho Bay, located along the coast of the Kii Peninsula, central Japan, is a small embayment with an area of $22.2 \mathrm{~km}^{2}$ and a mean depth of $12.7 \mathrm{~m}$ (Fig. 1). The shoreline of the bay is constituted mainly of rocky reefs, and partly of sandy beaches. Freshwater flows into the bay mainly from the Iseji River, which drains $39 \mathrm{~km}^{2}$ of forested land covered by evergreen broad-leaved trees $\left(\mathrm{C}_{3}\right.$ plants $)$ that are almost free of anthropogenic influence. The average flow rate of this river is $1.5 \times 10^{5} \mathrm{~m}^{3}$

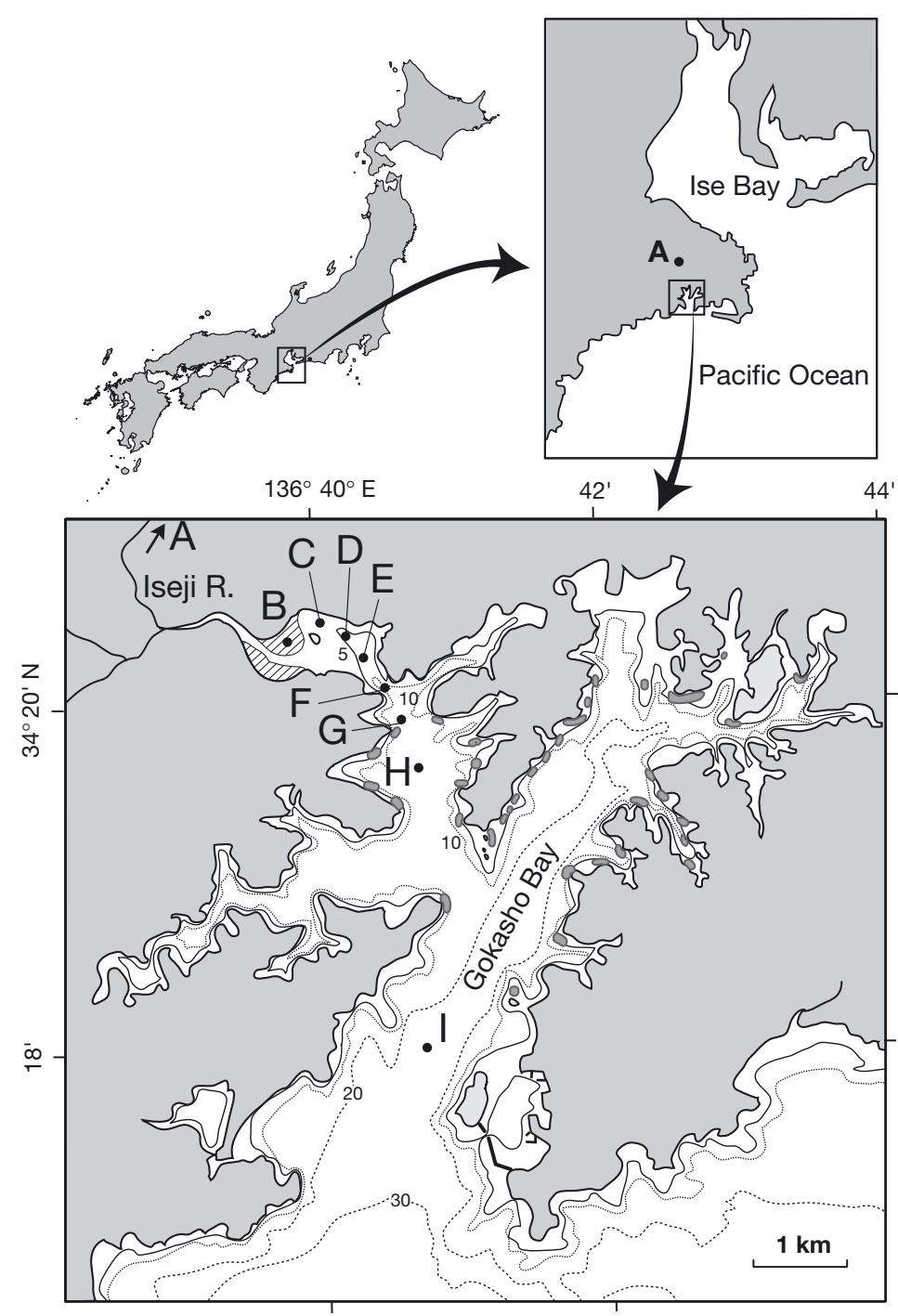

Fig. 1. Map of the study area showing the location of the mudflats (hatched area) and the sampling stations (Stns A to I) with depth contours (m). Dark areas indicate Sargassum beds $\mathrm{s}^{-1}$. The difference in tidal range between spring and neap tides attains $2.0 \mathrm{~m}$. Mudflats appear at the mouth of the Iseji River, extending over an area of 25 ha at the lowest ebb tide. During our sampling at Stn B, the mudflats were entirely bare, excluding a small amount of macroalgae which were found attached to small stones and free of vascular $\mathrm{C}_{4}$ saltmarsh plants. Marine macroalgae including Hizikia fusiformis, Sargassum hemiphyllum, $S$. horneri, $S$. patens, and $S$. piluliferum, grow rapidly during the winter and spring months and occur as dominant species in Gokasho Bay (Yokoyama et al. 1999), forming Sargassum beds at the central and inner part of the bay (Fig. 1). Theora lubrica occurs as a dominant species at the inner part of Gokasho Bay, attaining a maximum density of 1500 ind. $\mathrm{m}^{-2}$ (Yokoyama et al. 1996).

Sampling, isotopic analysis and data analysis: Theora lubrica, sedimentary organic matter $(\mathrm{SOM})$, particulate organic matter (POM) in suspended solids, and benthic microalgae on the mudflat were analyzed for their stable carbon and nitrogen isotope ratios. T. lubrica were collected from 6 stations (Fig. 1: Stns $\mathrm{C}$ to $\mathrm{H}$ ) in Gokasho Bay on April 26, 2001 with an Ekman grab and a $2 \mathrm{~mm}$ mesh sieve. The whole soft tissues of adult individuals ( $>10 \mathrm{~mm}$ in shell length) were picked from the shell, and their intestine was removed if contents were observed in it. The dissected soft tissues were washed in $1.2 \mathrm{~N} \mathrm{HCl}$ to remove traces of carbonate, dried to constant weight at $60^{\circ} \mathrm{C}$, and ground to a fine powder. At the same time of the animal collection, sediment samples were collected from the same stations with a plastic coring tube set within the Ekman grab. The surface layer of sediment (to $1 \mathrm{~cm}$ depth) was sampled, acidified with $1.2 \mathrm{~N} \mathrm{HCl}$ to remove carbonates, dried at $60^{\circ} \mathrm{C}$, and homogenized to measure the isotopic compositions of SOM.

It is necessary to determine the variability of $\delta^{13} \mathrm{C}$ and $\delta^{15} \mathrm{~N}$ of the potential food sources and how these values change seasonally, because isotopic compositions of primary producers can exhibit seasonal variability (e.g. Goering et al. 1990, Cloern et al. 2002). Therefore, POM and benthic microalgae were collected monthly during the period from April 2001 to May 2002. To determine the isotopic composition of the terrestrial and marine end-members, freshwater and seawater were obtained from Stn A $(9.1 \mathrm{~km}$ from the river mouth, $60 \mathrm{~m}$ above sea level), which is located near a headstream of the Iseji River, and from $1.0 \mathrm{~m}$ depth at Stn I near the mouth of Gokasho Bay, respectively. POM was obtained by filtration of the water on precombusted Whatman GF/F glass fiber filters, acidified $(1.2 \mathrm{~N} \mathrm{HCl})$ to 
remove carbonates, and dried at $60^{\circ} \mathrm{C}$. Subsamples of the water for POM samples were observed under microscopic examination to ascertain the content of POM and to determine the density of phytoplankton cells. Benthic microalgae were extracted from the surface sediments of the intertidal mudflat (Stn B) through a procedure from Couch (1989) as modified by Riera \& Richard (1996). Within 30 min the sediment was brought back to the laboratory and spread on a flat tray to a depth of ca. $1 \mathrm{~cm}$. A nylon screen (63 $\mu \mathrm{m}$ mesh) was laid upon the sediment surface, and a 4 to $5 \mathrm{~mm}$ layer of combusted sand with a diameter of 125 to $500 \mu \mathrm{m}$ was spread over it. The tray was held under fluorescent light and the sand was kept wet by spraying with filtered seawater. After 12 to $15 \mathrm{~h}$, the top $2 \mathrm{~mm}$ of the sand was removed by scraping, and sieved by rinsing with filtered seawater through a $63 \mu \mathrm{m}$ screen in order to separate the microalgae from the sand. Water containing the microalgae was then filtered on precombusted GF/F filters, rinsed with distilled water, and dried at $60^{\circ} \mathrm{C}$. A small portion of each microalgal sample was preserved in $10 \%$ neutral formalin and observed under microscopic examination to identify the species composition.

The ${ }^{15} \mathrm{~N}$ and ${ }^{13} \mathrm{C}$ composition of the samples was determined using a mass spectrometer (MAT 252, Finnigan MAT) coupled on-line, via a Finnigan ConFlo II interface, with an elemental analyzer (EA 1110, ThermoQuest Italia). Results are expressed in the standard $\delta$ unit notation where $\delta X=\left[\left(R_{\text {samples }} / R_{\text {reference }}\right)-1\right]$ $\times 10^{3}$, with $R={ }^{13} \mathrm{C} /{ }^{12} \mathrm{C}$ for carbon and ${ }^{15} \mathrm{~N} /{ }^{14} \mathrm{~N}$ for nitrogen, and reported relative to the Pee Dee Belemnite standard (PDB) for carbon and to atmospheric $\mathrm{N}_{2}$ for nitrogen.

In a system where 2 end-members of different isotope values are available to a consumer, the fraction that each end-member contributes to the diet can be calculated from the resulting $\delta^{13} \mathrm{C}$ and $\delta^{15} \mathrm{~N}$ of the consumer's tissues. The contribution ratio of the endmember to the diet of the consumer is determined by the dual isotope model (Yokoyama et al. 2002).

Results and discussion. Species composition of phytoplankton and benthic microalgae: Phytoplankton was scarcely found in the riverine POM collected at Stn A, and the majority of the suspended matter seemed to originate from decomposed plant debris. The bulk of POM collected from Stn I was phytoplankton. The density of cells was high from June through September, ranging from 370 to 830 cells ml$^{-1}$; after September the density decreased rapidly in the succeeding fall and winter months, resulting in $<100$ cells $\mathrm{ml}^{-1}$ (Fig. 2). Diatoms constituted the largest component of the flora of phytoplankton throughout the year, accounting for more than $90 \%$ of the total cells, except for January 2002, when unidentified dinoflagellates accounted for $24 \%$ of the total cells (Fig. 2). Skeletonema costatum, Chaetoceros spp., Nitzschia sp., Thalassiosira spp., Eucampia sp., Rhizosolenia spp., and Thalassionema sp., which are common phytoplankton in Japanese coastal waters, occurred as dominant or subdominant species. Microalgae on the mudflat (Stn B), which were extracted by using their motile ability, were dominated by pennate diatoms throughout the year (Table 1). There was no obvious seasonal variation in the species composition. Navicula sp. A appeared as the dominant species ( $>43 \%$ of the total cells) all the year round, except in October and December 2001, when Amphora sp. dominated. Subdominant species were $A$. ventricosa, Diploneis sp. Gyrosigma sp., Navicula sp. B, and Navicula sp. C, which belongs to Naviculaceae, and Bacillaria paradoxa, Cylindrotheca closterium, and Nitzschia sp., which belongs to Nitzschiaceae.

$\delta^{13} \mathrm{C}$ and $\delta^{15} \mathrm{~N}$ of potential food sources: Riverine POM had the lowest $\delta^{13} \mathrm{C}$ and $\delta^{15} \mathrm{~N}$ values among the 3 food sources, ranging from -27.3 (November) to $-24.3 \%$ (April), with a mean $( \pm \mathrm{SD})$ of $-26.5 \pm 0.8 \%$ o $(\mathrm{n}=$ 12 ), and -1.3 (May) to $2.4 \%$ (January) with a mean of $0.5 \pm 1.3 \%$ o $(\mathrm{n}=12)$, respectively (Fig. 3$)$. These values are within the range of isotopic compositions of terrestrial organic matter $\left(\mathrm{C}_{3}\right.$ plants $)$, i.e. $\delta^{13} \mathrm{C}$ ranging from -30 to $-23 \%$ with a modal value of ca. $-27 \%$ (e.g. Fry \& Sherr 1984, Boutton 1991) and $\delta^{15} \mathrm{~N}$ ranging from ca. -5 to $2 \%$ (e.g. Fry 1991). Marine POM had less negative $\delta^{13} \mathrm{C}$ values, ranging from -21.9 (December) to $-18.5 \%$ o (September) with a mean of $-20.4 \pm 0.9 \%$ $(\mathrm{n}=12)$, and had also higher $\delta^{15} \mathrm{~N}$ values ranging from 3.9 (February) to $7.4 \%$ (June) with a mean of $6.3 \pm$ $1.0 \%(\mathrm{n}=12)$. These values are within the range of values $\left(\delta^{13} \mathrm{C}:-18\right.$ to $-24 \%, \delta^{15} \mathrm{~N}$ : 3.0 to $12 \%$ ) which have been previously reported for marine organic matter in

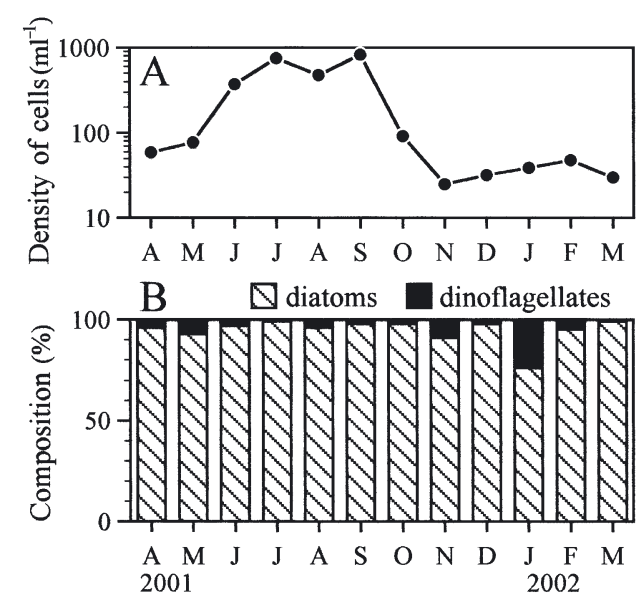

Fig. 2. Phytoplankton at Stn I. (A) Density of cells; (B) composition of diatoms and dinoflagellates in the total number of cells 
Table 1. Dominant and subdominant species of benthic microalgae collected from the mudflats in Gokasho Bay. Values in parentheses indicate the percentage of the total microalgal cells

\begin{tabular}{|c|c|c|c|}
\hline Date (mm/dd/yy) & & Species & \\
\hline Jun 7, 2001 & Navicula sp. A (69) & Bacillaria paradoxa (9) & Cylindrotheca closterium (7) \\
\hline Jun 25, 2001 & Navicula sp. A (85) & Amphora ventricosa (7) & Bacillaria paradoxa (5) \\
\hline Jul 24, 2001 & Navicula sp. A (94) & Bacillaria paradoxa (3) & Nitzschia sp. (2) \\
\hline Aug 23, 2001 & Navicula sp. A (52) & Navicula sp. B (17) & Amphora sp. (13) \\
\hline Sep 17, 2001 & Navicula sp. A (63) & Diploneis sp. (10) & Navicula sp. B (8) \\
\hline Oct 16,2001 & Amphora sp. (33) & Navicula sp. A (24) & Diploneis sp. (7) \\
\hline Nov 14, 2001 & Navicula sp. A (47) & Amphora sp. (19) & Bacillaria paradoxa (7) \\
\hline Dec 17, 2001 & Amphora sp. (36) & Navicula sp. A (31) & Cylindrotheca closterium (12) \\
\hline Jan 22, 2002 & Navicula sp. A (61) & Amphora sp. (12) & Navicula sp. B (9) \\
\hline Feb 22, 2002 & Navicula sp. A (45) & Gyrosigma sp. (9) & Navicula sp. B (9) \\
\hline Mar 19, 2002 & Navicula sp. A (53) & Navicula sp. C (11) & Unidentified Naviculaceae (8) \\
\hline Apr 18, 2002 & Navicula sp. A (43) & Gyrosigma sp. (18) & Navicula sp. B (6) \\
\hline May 27, 2002 & Navicula sp. A (48) & Amphora sp. (12) & Navicula sp. C (5) \\
\hline
\end{tabular}

$\Delta$ riverine $\mathrm{POM} \bigcirc \mathrm{O}$ marine $\mathrm{POM}$ benthic microalgae
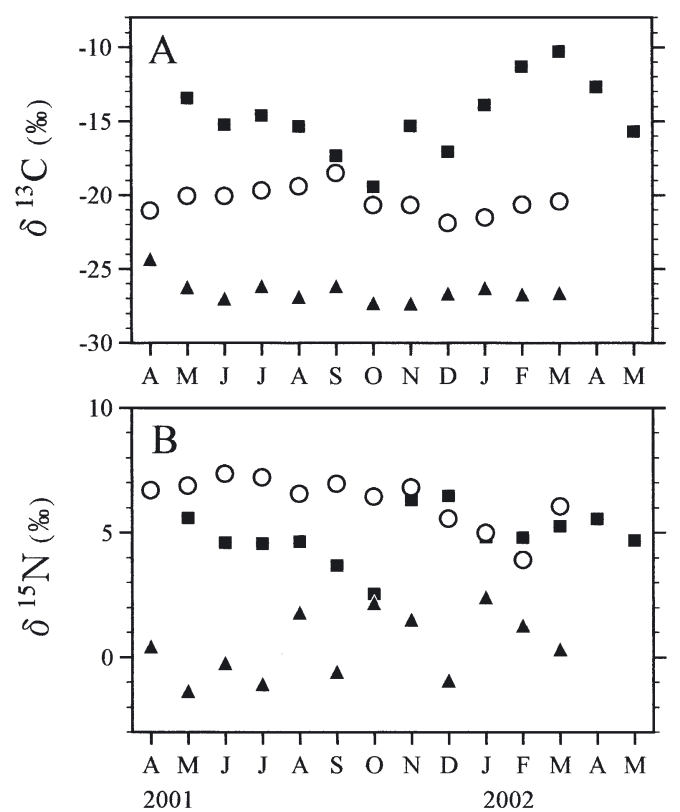

Fig. 3. Monthly $\delta^{13} \mathrm{C}(\mathrm{A})$ and $\delta^{15} \mathrm{~N}(\mathrm{~B})$ values $(\mathrm{n}=1)$ for riverine particulate organic matter (POM), marine POM and benthic microalgae from April 2001 to May 2002

temperate regions (Fry \& Sherr 1984, Gearing et al. 1984, Mariotti et al. 1984, Owens 1987, Boutton 1991, Wada \& Hattori 1991, France 1995). Benthic microalgae had the highest $\delta^{13} \mathrm{C}$ values among the 3 sources, showing a wide range of -19.5 (October) to $-10.3 \%$ (March) and a mean of $-14.7 \pm 2.5 \%$. $\delta^{15} \mathrm{~N}$ values for benthic microalgae had a range from 2.5 (October) to $6.5 \%$ (December) and a mean of $4.9 \pm 1.0 \%$ o $(n=13)$. The $\delta^{13} \mathrm{C}$ and $\delta^{15} \mathrm{~N}$ for benthic microalgae are similar to previously reported $\delta^{13} \mathrm{C}$ and $\delta^{15} \mathrm{~N}$ values, i.e. -20 to $-13 \%$ and 3 to $10 \%$, respectively (Couch 1989, Riera et al. 1996, 1999, 2000, Créach et al. 1997, Stribling \& Cornwell 1997, Wainright et al. 2000). Dominant macroalgae in Gokasho Bay, including Hizikia fusiformis, Sargassum hemiphyllum, S. horneri, S. patens, and $S$. piluliferum, have been found to have a mean $\delta^{13} \mathrm{C}$ of $-15.0 \pm 2.5 \%$ o $(\mathrm{n}=127)$, and a mean $\delta^{15} \mathrm{~N}$ of $8.1 \pm 1.0 \%$ o $(n=127)$ (Y.I. et al. unpubl.). There was a clear difference both in $\delta^{13} \mathrm{C}$ and $\delta^{15} \mathrm{~N}$ between riverine and marine POM, with their distributions showing no overlap throughout the year (Fig. 3). There were significant differences both in $\delta^{13} \mathrm{C}$ (2-way ANOVA, p < $0.001)$ and $\delta^{15} \mathrm{~N}(\mathrm{p}<0.05)$ between benthic microalgae and marine POM. $\delta^{13} \mathrm{C}$ values for macroalgae were close to values for benthic microalgae, whereas macroalgae were enriched with ${ }^{15} \mathrm{~N}$ in comparison with other sources, showing significant differences between them (Mann-Whitney test, $\mathrm{p}<0.001$ ).

$\delta^{13} \boldsymbol{C}$ and $\delta^{15} \mathbf{N}$ of SOM: Isotopic compositions of SOM (Table 2) were intermediate between those of riverine and marine POM (Fig. 4). SOM at Stn C, the closest station to the mudflats, had $\delta^{13} \mathrm{C}$ values of $-24.9 \%$ and $\delta^{15} \mathrm{~N}$ of $3.0 \%$. At the neighboring station (Stn D) both the $\delta^{13} \mathrm{C}$ and $\delta^{15} \mathrm{~N}$ values decreased slightly (-25.4 and $2.5 \%$, respectively), and then they progressively increased toward the seaward station (Stn $\mathrm{H})$, where the most enriched $\delta^{13} \mathrm{C}$ and $\delta^{15} \mathrm{~N}$ values (-21.0 and 5.4\%o, respectively) were found. This distribution suggests that organic matter in the sediment consisted of terrestrial and marine end-members and that the compositions reflected a physical and progressive mixing of these 2 components, as shown in other studies (e.g. Peters et al. 1978, Wada et al. 1987).

Food sources of Theora lubrica: T. lubrica exhibited spatial $\delta^{13} \mathrm{C}$ and $\delta^{15} \mathrm{~N}$ variations; the mean $\delta^{13} \mathrm{C}$ ranged from -17.8 to $-16.0 \%$, and the mean $\delta^{15} \mathrm{~N}$ ranged from 7.5 to $9.4 \%$ o (Table 2). Given a presumptive $1.0 \%$ trophic shift in the $\delta^{13} \mathrm{C}$ (DeNiro \& Epstein 1978, Fry \& 
Sherr 1984) and $3 \%$ shift in the $\delta^{15} \mathrm{~N}$ (DeNiro \& Epstein 1981, Minagawa \& Wada 1984), the expected $\delta^{13} \mathrm{C}$ and $\delta^{15} \mathrm{~N}$ values of the T. lubrica diet would have $\delta^{13} \mathrm{C}$ and $\delta^{15} \mathrm{~N}$ values ranging from -18.8 to $-17.0 \%$, and from 4.5 to $6.4 \%$, respectively (Fig. 4 ).

The large differences in $\delta^{13} \mathrm{C}$ between the hypothetical diet of Theora lubrica and riverine POM (7.7 to $9.5 \%$ ) suggest that riverborne terrestrial organic matter is not directly utilized by this species. The $\delta^{13} \mathrm{C}$ values for the hypothetical diet of T. lubrica were intermediate between those of marine POM and benthic microalgae (Fig. 4). The hypothetical diet exhibited significantly different $\delta^{13} \mathrm{C}$ variations between stations along the estuarine gradient (1-way ANOVA, p < 0.001). The diet at Stn $C$ had the most positive $\delta^{13} \mathrm{C}$ signature; the $\delta^{13} \mathrm{C}$ decreased as the collection station was shifted seaward (Stn F). These results suggest that $T$. lubrica incorporates a mixture of benthic diatoms and marine phytoplankton, and that the relative importance of these 2 sources changed along the estuarine gradient.

Kikuchi \& Tanaka (1976) clarified that it takes ca. 8 to $12 \mathrm{wk}$ in winter to attain the minimum reproductive size (5 to $6 \mathrm{~mm}$ in shell length) after settlement of Theora lubrica. Assuming that the $\delta^{13} \mathrm{C}$ and $\delta^{15} \mathrm{~N}$ values of adult individuals of T. lubrica collected in April reflect only the isotopic compositions of the diets for the 3 mo prior to the collection due to their rapid growth, the mean $\delta^{13} \mathrm{C}$ and $\delta^{15} \mathrm{~N}$ values of marine POM and benthic microalgae during the February to April period, i.e. -20.7 and $5.6 \%$ for marine POM $(x)$, and -11.4 and $5.2 \%$ for benthic microalgae $(z)$, respectively (Fig. 4), should be used for a quantitative assessment of the proportions of these 2 sources in the diet. The contribution ratio $(\mathrm{CR}, \%)$ of benthic microalgae to the diet to $T$. lubrica at $\mathrm{Stn} C$ can be calculated as $(a / b) \times 100=$ $42 \%\left(a=\right.$ distance between $x$ and $z_{i} b=$ distance between $x$ and $z$ ) based on the dual isotope model (Yokoyama et al. 2002). This result indicates that benthic microalgae can serve as an important food source

Table 2. $\delta^{13} \mathrm{C}(\%)$ and $\delta^{15} \mathrm{~N}(\%)$ for sedimentary organic matter (SOM) and Theora lubrica. Isotopic values for T. lubrica indicate the mean \pm SD. Number of samples is given in parentheses

\begin{tabular}{|c|c|c|c|c|}
\hline \multirow{2}{*}{ Stn } & \multicolumn{2}{|c|}{ SOM } & \multicolumn{2}{|c|}{ Theora lubrica } \\
\hline & $\delta^{13} \mathrm{C}$ & $\delta^{15} \mathrm{~N}$ & $\delta^{13} \mathrm{C}$ & $\delta^{15} \mathrm{~N}$ \\
\hline $\mathrm{C}$ & -24.9 & 3.0 & $-16.0 \pm 0.3(7)$ & $7.7 \pm 0.2(7)$ \\
\hline $\mathrm{D}$ & -25.4 & 2.5 & $-16.7 \pm 0.4(7)$ & $7.5 \pm 0.2(7)$ \\
\hline $\mathrm{E}$ & -24.2 & 3.6 & $-17.2 \pm 0.2(7)$ & $7.7 \pm 0.2(7)$ \\
\hline $\mathrm{F}$ & -22.8 & 4.7 & $-17.8 \pm 0.1(8)$ & $8.2 \pm 0.2(8)$ \\
\hline G & -21.9 & 4.7 & $-17.7 \pm 0.2(11)$ & $8.4 \pm 0.2(11)$ \\
\hline $\mathrm{H}$ & -21.0 & 5.4 & $-17.2 \pm 0.2(10)$ & $9.4 \pm 0.2(10)$ \\
\hline
\end{tabular}

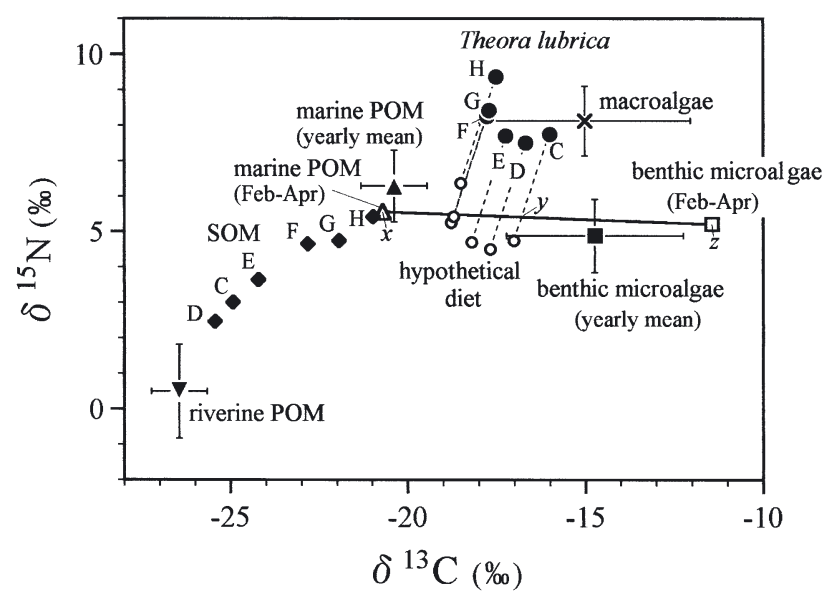

Fig. 4. Theora lubrica. Dual isotope plot of $\delta^{13} \mathrm{C}$ and $\delta^{15} \mathrm{~N}$, hypothetical diet and potential food sources. Error bars indicate standard deviations during the sampling period. Upper case letters $\mathrm{C}$ to $\mathrm{H}$ indicate the sampling stations. $y$ is the point where the solid line $(x z)$ and the broken line intersect. See text for $x$ and $z$

for T. lubrica near the mudflats. As the habitat is shifted seaward, however, marine POM increasingly makes a predominant contribution, accounting for 78 to $79 \%$ of the CR of the diet at Stns F to H.

Benthic microalgae contribute a significant proportion of the total primary production in the subtidal part of estuaries via their resuspension and diffusion from the tidal flats (Shaffer \& Sullivan 1988, Lucas et al. 2001) and/or in situ production on the subtidal bottom (Cahoon 1999, Blackford 2002). The isotope composition of SOM in Gokasho Bay estuary, however, showed that a large part of SOM near the mudflats corresponded to terrestrial materials transported by the river, and the part originating from benthic microalgae was low. The discrepancy of the isotope composition between SOM and Theora lubrica diets suggests that this bivalve preferentially feeds on microalgae with its siphon stretched out over the bottom surface (Kikuchi 1981). Rosenberg (1993) found the co-existence of suspension and deposit-feeding in the semelid bivalve Abra alba. Observations of feeding behavior of $T$. lubrica in the laboratory, however, could not reveal suspension feeding. It seems likely that $T$. lubrica feeds on benthic microalgae which are carried from the mudflats into the subtidal habitat of the bivalve, and/or benthic microalgae which are produced on the subtidal bottoms where the bivalve can feed on them directly.

There was a significant difference between stations among $\delta^{15} \mathrm{~N}$ values for Theora lubrica (1-way ANOVA, $\mathrm{p}<0.001$ ). At 3 stations near the mudflats (Stns C to E) T. lubrica had a similar $\delta^{15} \mathrm{~N}$ value $(7.5$ to $7.7 \%$ o); however, it increased to $9.4 \%$ at Stn H (Table 2, Fig. 4). 
Sargassum beds are well developed on the rocky and stony bottoms around Stn H (Fig. 1). The enrichment of ${ }^{15} \mathrm{~N}$ in $T$. lubrica tissue toward Stn H may be due to the incorporation of macroalgal detritus, although the dietary proportion of macroalgae could not be determined.

Recent stable isotope studies have suggested that riverborne terrestrial organic matter is relatively inconsequential in estuarine food webs, and that autochthonous production by saltmarsh plants and/or micro- and macro-algae is important in supporting estuarine secondary productivity (e.g. Simenstad \& Wissmar 1985, Peterson \& Howarth 1987, Sullivan \& Moncreiff 1990, Deegan \& Garritt 1997, Page 1997, Kurata et al. 2001, Takai et al. 2002). Increasing attention has particularly focused on benthic microalgae as a food source for the meiobenthos (Couch 1989), macrobenthos (Haines \& Montague 1979, Currin et al. 1995, Riera \& Richard 1996, Créach et al. 1997, Kang et al. 1999, Riera et al. 1999), megabenthos (Riera et al. 2000) and fish (Kneib et al. 1980, Wainright et al. 2000). Most of these animals, except the brown shrimp Penaeus aztecus (Riera et al. 2000), are inhabitants of the intertidal zone. The present study provides evidence of the importance of benthic microalgae as well as coastal phytoplankton as a food source for this subtidal deposit-feeding bivalve.

Theora lubrica is widely distributed in eutrophic basins, which are frequently associated with phytoplankton blooms, and in the innermost part of bays and lagoons near shorelines (Horikoshi 1990, Kikuchi 1991). Saito et al. (1998) suggested that active phytoplankton production supports the T. lubrica population via benthic-pelagic coupling; however, not only phytoplankton but also benthic microalgae can support the population of this bivalve.

Acknowledgements. We wish to thank Y. Yamada for his valuable suggestions. This research was conducted under the project study entitled 'Integrated study on the development of natural cyclical functions through forest, agricultural and aquatic ecosystems', which is funded by the Agriculture, Forestry and Fisheries Research Council, Japan.

\section{LITERATURE CITED}

Blackford JC (2002) The influence of microphytobenthos on the Northern Adriatic ecosystem: a modelling study. Estuar Coast Shelf Sci 55:109-123

Boutton TW (1991) Stable carbon isotope ratios of natural materials. II. Atmospheric, terrestrial, marine, and freshwater environments. In: Coleman DC, Fry B (eds) Carbon isotope techniques. Academic Press, San Diego, p 173-185

Cahoon LB (1999) The role of benthic microalgae in neritic ecosystems. Oceanogr Mar Biol Annu Rev 37:47-86

Cloern JE, Canuel EA, Harris D (2002) Stable carbon and nitrogen isotope composition of aquatic and terrestrial plants of the San Francisco Bay estuarine system. Limnol Oceanogr 47:713-729

Couch CA (1989) Carbon and nitrogen stable isotopes of meiobenthos and their food resources. Estuar Coast Shelf Sci 28:433-441

Créach V, Schricke MT, Bertru G, Mariotti A (1997) Stable isotopes and gut analyses to determine feeding relationships in saltmarsh macroconsumers. Estuar Coast Shelf Sci 44:599-611

Currin CA, Newell SY, Paerl HW (1995) The role of standing dead Spartina alterniflora and benthic microalgae in salt marsh food webs: considerations based on multiple stable isotope analysis. Mar Ecol Prog Ser 121:99-116

Deegan LA, Garritt RH (1997) Evidence for spatial variability in estuarine food webs. Mar Ecol Prog Ser 147:31-47

DeNiro MJ, Epstein S (1978) Influence of diet on the distribution of carbon isotopes in animals. Geochim Cosmochim Acta 42:495-506

DeNiro MJ, Epstein S (1981) Influence of diet on the distribution of nitrogen isotopes in animals. Geochim Cosmochim Acta 45:341-351

Fontugne MR, Jouanneau JM (1987) Modulation of the particulate organic carbon flux to the ocean by a macrotidal estuary: evidence from measurements of carbon isotopes in organic matter from the Gironde system. Estuar Coast Shelf Sci 24:377-387

France RL (1994) Nitrogen isotopic composition of marine and freshwater invertebrates. Mar Ecol Prog Ser 115:205-207

France RL (1995) Carbon-13 enrichment in benthic compared to planktonic algae: foodweb implications. Mar Ecol Prog Ser 124:307-312

Fry B (1991) Stable isotope diagrams of freshwater food webs. Ecology 72:2293-2297

Fry B, Sherr EB (1984) $\delta^{13} \mathrm{C}$ measurements as indicators of carbon flow in marine and freshwater ecosystems. Contrib Mar Sci 27:13-47

Gearing JN, Gearing PJ, Rudnick DT, Requejo AG, Hutchins MJ (1984) Isotopic variability of organic carbon in a phytoplankton-based, temperate estuary. Geochim Cosmochim Acta 48:1089-1098

Goering J, Alexander V, Haubenstock N (1990) Seasonal variability of stable carbon and nitrogen isotope ratios of organisms in a North Pacific bay. Estuar Coast Shelf Sci 30:239-260

Haines EB, Montague CL (1979) Food sources of estuarine invertebrates analyzed using ${ }^{13} \mathrm{C} /{ }^{12} \mathrm{C}$ ratios. Ecology 60: $48-56$

Hayward BW, Stephenson AB, Morley M, Riley JL, Grenfell HR (1997) Faunal changes in Waitemata Harbour sediments, 1930s-1990s. J R Soc NZ Zool 27:1-20

Horikoshi M (1990) Macrobenthic communities in Japanese coastal waters. In: Oceanographic Society of Japan (ed) Coastal oceanography of Japanese islands (Suppl vol) Tokai University Press, Tokyo, p 283-311

Imabayashi H (1986) Effect of oxygen-deficient water on the settled abundance and size composition of the bivalve Theora lubrica. Bull Jpn Soc Sci Fish 5:391-397

Imabayashi H, Tsukuda S (1984) A population ecology of the small bivalve Theora lubrica in northern Bingo-Nada. Bull Jpn Soc Sci Fish 50:1855-1862

Kang CK, Sauriau PG, Richard P, Blanchard GF (1999) Food sources of the infaunal suspension-feeding bivalve Cerastoderma edule in a muddy sandflat of Marennes-Oléron Bay, as determined by analyses of carbon and nitrogen stable isotopes. Mar Ecol Prog Ser 187:147-158

Kikuchi T (1981) Benthos activity with special reference to bioturbation. Bull Coast Oceanogr 18:67-77 
Kikuchi T (1991) Macrobenthic succession in the organically polluted waters, and ecological characteristics of some pollution indicator species. In: Mauchline J, Nemoto T (eds) Marine biology, its accomplishment and future prospect. Hokusensha, Tokyo, p 145-163

Kikuchi T, Tanaka M (1976) Some aspects on the ecology of a short-lived semelid bivalve, Theora lata (Hinds), with special reference to its opportunistic life history. Physiol Ecol Jpn 17:261-271

Kneib RT, Stiven AE, Haines EB (1980) Stable carbon isotope ratios in Fundulus heteroclitus (L.) muscle tissue and gut contents from a North Carolina Spartina marsh. J Exp Mar Biol Ecol 46:89-98

Kurata K, Minami H, Kikuchi E (2001) Stable isotope analysis of food sources for salt marsh snails. Mar Ecol Prog Ser 223:167-177

Lucas CH, Banham C, Holligan PM (2001) Benthic-pelagic exchange of microalgae at a tidal flat. 2. Taxonomic analysis. Mar Ecol Prog Ser 212:39-52

Mariotti A, Lancelot C, Billen G (1984) Natural isotopic composition of nitrogen as a tracer of origin for suspended organic matter in the Scheldt estuary. Geochim Cosmochim Acta 48:549-555

Minagawa M, Wada E (1984) Stepwise enrichment of ${ }^{15} \mathrm{~N}$ along food chains: further evidence and the relation between $\delta^{15} \mathrm{~N}$ and animal age. Geochim Cosmochim Acta 48:1135-1140

Owens NJP (1987) Natural variations in ${ }^{15} \mathrm{~N}$ in the marine environment. Adv Mar Biol 24:389-451

Page HM (1997) Importance of vascular plant and algal production to macro-invertebrate consumers in a southern California salt marsh. Estuar Coast Shelf Sci 45:823-834

Peters KE, Sweeney RE, Kaplan IR (1978) Correlation of carbon and nitrogen stable isotope ratios in sedimentary organic matter. Limnol Oceanogr 23:598-604

Peterson BJ, Howarth RW (1987) Sulfur, carbon, and nitrogen isotopes used to trace organic matter flow in the salt-marsh estuaries of Sapelo Island, Georgia. Limnol Oceanogr 32: $1195-1213$

Poore GCB, Rainer SA (1979) A 3-year study of benthos of muddy environments in Port Phillip Bay, Victoria, Australia. Estuar Coast Mar Sci 9:477-498

Riera P, Richard P (1996) Isotopic determination of food sources of Crassostrea gigas along a trophic gradient in the estuarine bay of Marennes-Oléron. Estuar Coast Shelf Sci 42:347-360

Riera P, Richard P, Grémare A, Blanchard G (1996) Food source of intertidal nematodes in the Bay of MarennesOléron (France), as determined by dual stable isotope analysis. Mar Ecol Prog Ser 142:303-309

Riera P, Stal LJ, Nieuwenhuize J, Richard P, Blanchard G, Gentil F (1999) Determination of food sources for benthic invertebrates in a salt marsh (Aiguillon Bay, France) by

Editorial responsibility: Otto Kinne (Editor),

Oldendorf/Luhe, Germany carbon and nitrogen stable isotopes: importance of locally produced sources. Mar Ecol Prog Ser 187:301-307

Riera P, Montagna PA, Kalke RD, Richard P (2000) Utilization of estuarine organic matter during growth and migration by juvenile brown shrimp Penaeus aztecus in a South Texas estuary. Mar Ecol Prog Ser 199:205-216

Rosenberg R (1993) Suspension feeding in Abra alba (Mollusca). Sarsia 78:119-121

Saito H, Ueno M, Hayashi I (1998) Temporal fluctuation in the abundance of a semelid bivalve, Theora fragilis (A. Adams) in Maizuru Bay, Sea of Japan. Hydrobiologia 375/376:151-163

Shaffer GP, Sullivan MJ (1988) Water column productivity attributable to displaced benthic diatoms in well-mixed shallow estuaries. J Phycol 24:132-140

Simenstad CA, Wissmar RC (1985) $\delta^{13} \mathrm{C}$ evidence of the origins and fates of organic carbon in estuarine and nearshore food webs. Mar Ecol Prog Ser 22:141-152

Stribling JM, Cornwell JC (1997) Identification of important primary producers in a Chesapeake Bay tidal creek system using stable isotopes of carbon and sulfur. Estuaries 20:77-85

Sullivan MJ, Moncreiff CA (1990) Edaphic algae are an important component of salt marsh food-webs: evidence from multiple stable isotope analyses. Mar Ecol Prog Ser 62:149-159

Takai N, Mishima Y, Yorozu A, Hoshika A (2002) Carbon sources for demersal fish in the western Seto Inland Sea, Japan, examined by $\delta^{13} \mathrm{C}$ and $\delta^{15} \mathrm{~N}$ analyses. Limnol Oceanogr 47:730-741

Wada E, Hattori A (1991) Nitrogen in the sea: forms, abundances, and rate processes. CRC Press, Boca Raton, FL

Wada E, Minagawa M, Mizutani H, Tsuji T, Imaizumi R, Karasawa K (1987) Biogeochemical studies on the transport of organic matter along the Otsuchi River watershed, Japan. Estuar Coast Shelf Sci 25:321-336

Wainright SC, Weinstein MP, Able KW, Currin CA (2000) Relative importance of benthic microalgae, phytoplankton and the detritus of smooth cordgrass Spartina alterniflora and the common reed Phragmites australis to brackishmarsh food webs. Mar Ecol Prog Ser 200:77-91

Yokoyama H, Toda S, Abo K, Yamamoto S (1996) Macrobenthic fauna of Gokasho Bay: comparison of 1993 and 1941 surveys. Bull Natl Res Inst Aquacult 25:23-42

Yokoyama H, Ishihi Y, Toyokawa M, Yamamoto S, Ajisaka T (1999) Community structure on sargassoceous beds in Gokasho Bay II. Seasonal growth, maturation periods of sargassoceous species, and annual net production of seaweeds. Bull Natl Res Inst Aquacult 28:27-37

Yokoyama H, Higano J, Adachi K, Ishihi Y, Yamada Y, Pichitkul P (2002) Evaluation of shrimp polyculture system in Thailand based on stable carbon and nitrogen isotope rations. Fish Sci 68:745-750

Submitted: November 12, 2002; Accepted: April 3, 2003

Proofs received from author(s): June 10, 2003 